\title{
Relationship Between Phosphorylation and Synthesis of Goldfish Optic Nerve Proteins During Regeneration
}

\author{
Denis C. Larrivee and Bernice Grafstein \\ Department of Physiology, Cornell University Medical College, New York, New York 10021
}

\begin{abstract}
After intraocular injection of radiolabeled phosphate and ${ }^{3} \mathrm{H}$ proline, the labeling of goldfish optic nerve proteins was monitored over a 7 week period of regeneration following a lesion to the optic tract. Labeled phosphate incorporation into total nerve protein increased to a peak value about twice that in normal nerve at 3 weeks after injury, then declined to slightly above normal by 7 weeks. Incorporation of ${ }^{3} \mathrm{H}$ proline showed a higher rise and a steeper decline, with values still significantly above normal at 7 weeks. Two-dimensional gel electrophoresis revealed that almost all the individual proteins examined underwent an increase in ${ }^{3} \mathrm{H}$ proline incorporation with a peak at about 3 weeks. However, only 4 proteins showed an increase in incorporation of ${ }^{32} \mathrm{P}$ correlated with the increase in ${ }^{3} \mathrm{H}$-proline. The closest correlation was seen for protein 4 , the equivalent of the growthassociated protein GAP-43; for the other 3 proteins $(15,31$, and 38$){ }^{32} \mathrm{P}$ incorporation remained elevated even when ${ }^{3} \mathrm{H}$ proline incorporation had declined. Two other proteins $(24 e$ and 48) showed increased ${ }^{32} \mathrm{P}$ incorporation not correlated with ${ }^{3} \mathrm{H}$-proline changes. Several proteins showed a decrease in ${ }^{32} \mathrm{P}$ incorporation, even though ${ }^{3} \mathrm{H}$-proline incorporation was increased. For example, the phosphorylation of ON2, a neuronal intermediate filament protein, showed a long-lasting decline, which was already evident at 1 woek and had not yet returned to normal by 7 weeks. Other proteins in this group $(33,37$, and 46$)$ showed a faster recovery. Proteins 32, 44, 45 showed reduced ${ }^{32} \mathrm{P}$ labeling only at 3 weeks, whereas protein 9 showed a large reduction at 1 week followed by a relatively rapid recovery. For a few proteins the changes in ${ }^{32} \mathrm{P}$ incorporation were accompanied by a shift in $\mathrm{pl}$. Some proteins failed to show any significant change in phosphorylation despite increased ${ }^{3} \mathrm{H}$-proline incorporation. The proteins that showed a correlation between ${ }^{32} \mathrm{P}$ and ${ }^{3} \mathrm{H}$-proline incorporation during the first 3 weeks of regeneration may be limited in their phosphorylation primarily by the amount of substrate protein present. Those that failed to show any correlation may be posttranslationally modified by protein kinase activity or may undergo early phosphorylation followed by a variable degree of dephosphorylation. In some cases, the phosphorylation events appeared to be primarily associated with either axonal out-
\end{abstract}

Received Mar. 28, 1988; revised July 22, 1988; accepted July 25, 1988.

This work was supported by Research Grant NS-14967 from NINCDS and by a Fellowship from the Spinal Cord Research Foundation (PVA). We are grateful to Ms. Janet Encarnacion for help in preparation of the figures and Ms. Connie Gutierrez for typing the manuscript.

Correspondence should be addressed to Dr. D. C. Larrivee at the above address. Copyright (C) 1989 Society for Neuroscience $0270-6474 / 89 / 020574-08 \$ 02.00 / 0$ growth (proteins 4, 9, 33, and ON2) or synaptogenesis (proteins $15,31,37,38$, and 48 ). Thus, the progress of regeneration is more closely correlated with changes in posttranslational processing of these proteins than with changes in their gene expression.

The goldfish optic nerve regenerates after injury, showing vigorous axonal outgrowth and eventually reestablishing its synaptic connections with appropriate neurons in the optic tectum (Attardi and Sperry, 1963). The axonal events are accompanied by major metabolic alterations of the cell body (Grafstein, 1986), including a profound increase in protein synthesis (Grafstein et al., 1987; Perry et al., 1987). We have also observed prominent changes in phosphorylation of optic nerve proteins (Larrivee and Grafstein, 1987a, b). Phosphorylation is a mechanism that is known to be capable of modulating protein function (Nestler et al., 1984). Its possible role in neuronal regeneration is supported by the importance of protein-phosphorylating mechanisms in neuronal development and differentiation (Murphy et al., 1983; Turner et al., 1984; Girard et al., 1985; Burgess et al., 1986; Cremins et al., 1986).

The object of the present study was to determine whether changes in phosphorylation were specifically associated with one or another stage of regeneration. The time course of regencration in the goldfish optic axons has been well worked out (reviewed by Grafstein, 1986). Beginning a few days after a lesion, the retinal ganglion cell axons show rapid elongation until they reach the optic tectum at 2-3 weeks and then a slower rate of outgrowth within the tectum, accompanied by profuse branching. Synapse formation commences shortly after the axons begin to enter the tectum, and synaptic density increases rapidly thereafter. The number of synapses may already be close to normal hy 4-5 weeks (Hayes and Meyer, 1986), but synaptogenesis continues for several months (Murray and Edwards, 1982), during which refinement of the retinotectal projection is proceeding.

It might be expected that the various stages of regeneration would be characterized by the preferential production of different axonal constituents. Nevertheless, virtually all axonally transported proteins undergo increased synthesis with much the same time course (Grafstein et al., 1987; Perry et al., 1987). This may indicate that in this system protein synthesis is dominated by a requirement for replacement of many different axonal proteins that are turning over more rapidly during regeneration (Whitnall and Grafstein, 1982), rather than a specific requirement for axonal constituents essential for one or another phase of regeneration.

In contrast to the pervasive increase in synthesis of axonally transported proteins, there is much more variability in phos- 
phorylation during regeneration. Some axonal proteins show an increase, others show a decrease (Larrivee and Grafstein, 1987b). In our previous work, these changes were measured only at 3 weeks after a lesion of the optic axons. In the present study, we have systematically examined, throughout the course of regeneration, the relationship between changes in phosphorylation and changes in amino acid incorporation in the same proteins. The observations were made in the intact segment of the optic nerve after an optic tract lesion and thus indicate alterations in the proteins in the axon segment that remains attached to the cell body ( $c f$. Perry et al., 1987). They could therefore represent changes in the synthesis, processing or axonal transport of proteins being conveyed to the regenerating segment of axon. We report here that in this case ${ }^{32} \mathrm{P}$ incorporation into axonal proteins is usually not correlated with ${ }^{3} \mathrm{H}-$ proline incorporation.

\section{Materials and Methods}

Animals. Experiments were done on goldfish (Carassius auratus) 3-4 inches in body length (Ozark Fisheries, Stoutland, MO), which were maintained in 10 gallon tanks at $20^{\circ} \mathrm{C}$ on a schedule of $14 \mathrm{hr}$ light $/ 10$ hr dark.

Surgical procedures. The left optic tract was cut intracranially about $1 \mathrm{~mm}$ in front of the tectum as described previously (Larrivee and Grafstein, 1987a).

Radioactive labeling. For in vivo labeling, $3 \mu \mathrm{l}$ of an aqueous solution of $\mathrm{H}_{3}{ }^{32} \mathrm{PO}_{4}$ (usually containing $50 \mu \mathrm{Ci}$; about $1000 \mathrm{mCi} / \mathrm{mmol}$; New England Nuclear) was injected into the vitreous humor of the right eye, followed by $3 \mu{ }^{3} \mathrm{H}-l$-proline solution (containing $50 \mu \mathrm{Ci}$; about 60 $100 \mathrm{Ci} / \mathrm{mmol} ; \mathrm{ICN}$ ). The animals were killed $17 \mathrm{hr}$ later and a segment of nerve extending from about $1 \mathrm{~mm}$ behind the eye to the site of the lesion was taken.

Two-dimensional gel electrophoresis. Groups of 3 nerves were homogenized in $75 \mu$ l of lysis buffer containing $11.4 \mathrm{gm}$ urea, $0.2 \mathrm{gm}$ SDS, $0.16 \mathrm{ml} \mathrm{5-7}$ ampholines, $0.16 \mathrm{ml} \mathrm{4-6}$ ampholines, $0.08 \mathrm{ml} \mathrm{3.5-10}$ ampholines, and $0.154 \mathrm{gm}$ dithiothreitol $/ 20 \mathrm{ml}$ of aqueous solution. A $5 \mu \mathrm{l}$ aliquot was removed for determination of the radioactivity in TCAsoluble and TCA-precipitable material, and the remainder of the sample was applied directly to the electrophoresis gel.

Two-dimensional PAGE electrophoresis was performed according to the procedure of O'Farrell (1975), with modifications as described by Perry et al. (1985). Three to seven gels were prepared for each determination. Preparation of autoradiograms from the gels and analysis of individual protein spots for measurement of ${ }^{32} \mathrm{P}$ labeling were carried out as described previously (Larrivee and Grafstein, 1987b). For measurement of ${ }^{3} \mathrm{H}$-proline content, the appropriate regions, determined by using the autoradiograms as templates, were cut out of the gels, solubilized, and subjected to liquid scintillation counting as described by Perry et al. (1987). With this technique, it was possible to measure ${ }^{3} \mathrm{H}-$ proline incorporation into some proteins, e.g., ON2, which had not been fluorographically detectable with ${ }^{3} \mathrm{H}$-proline labeling alone (Perry et al., 1987).

\section{Results}

\section{Time course of labeling of total nerve protein during} regeneration

The incorporation of intraocularly injected radiophosphate into optic nerve protein was increased after transection of the optic tract (Fig. 1 $A$ ). The maximum effect, seen at 3 weeks, representcd an increase to about twice that seen in the normal nerve. This level was maintained at 5 weeks, then declined significantly, but was still somewhat above normal at 7 weeks. The change in ${ }^{32} \mathrm{P}$ incorporation was much smaller than that seen with incorporation of radioactively labeled amino acid, which was increased more than 10 -fold at 3 weeks (Fig. 1B). In a previous study, the peak of ${ }^{3} \mathrm{H}$-proline incorporation was even higher (Perry et al., 1987), being seen at 2 weeks, a time point not included in the present study. By 5 weeks, ${ }^{3} \mathrm{H}$-proline in- corporation had declined precipitously to about 4 times control levels, and had declined further by 7 weeks, although it was still significantly above normal. Our previous observations indicate that ${ }^{3} \mathrm{H}$-proline incorporation does not recover completely until after 12 weeks (Perry et al., 1987).

\section{Time course of changes in individual proteins}

Approximately 20 nerve proteins (Fig. 2) become labeled in the optic nerve after injection of inorganic radiophosphate into the eye (Larrivee and Grafstein, 1987b). Many of them showed substantial changes in phosphorylation in the course of regeneration, involving either an increase or a decrease in ${ }^{32} \mathrm{P}$ incorporation. All of them are probably neuronal proteins, although some may be present in glial cells as well (Larrivee and Grafstein, 1987b).

Proteins showing increased phosphorylation in tandem with increased ${ }^{3} \mathrm{H}$-proline incorporation. Proteins $4,15,31$, and 38 showed an increase in phosphorylation during the first 3 weeks of regeneration, concomitant with the increase in ${ }^{3} \mathrm{H}$-proline incorporation (Fig. 3, $A, B$ ). The maximum relative increase in ${ }^{32} \mathrm{P}$ incorporation was generally less than that seen for ${ }^{3} \mathrm{H}$-proline (Table 1). By 1 week protein 4 already displayed a particularly large change in ${ }^{32} \mathrm{P}$ incorporation, but significant changes were also observed for proteins 15 and 38 . On the other hand, protein 31 was still essentially unchanged at this time (Fig. $3 B$ ). After 3 weeks ${ }^{3} \mathrm{H}$-proline incorporation into these 4 proteins declined sharply but ${ }^{32} \mathrm{P}$ incorporation remained almost constant in proteins 15,31 , and 38 , whereas protein 4 showed a more marked decline.

Other proteins showing increased phosphorylation. A few proteins showed significantly increased incorporation of ${ }^{32} \mathrm{P}$ not obviously linked to ${ }^{3} \mathrm{H}$-proline incorporation (Fig. 3C). One such case was protein $24 \mathrm{e}$, which showed an increase in ${ }^{32} \mathrm{P}$ incorporation that was relatively small (Table 1) but reproducible, superimposed on an already high level of incorporation in the normal nerve (Fig. 2B). Some increase in incorporation was already evident in this protein by 1 week, followed by a slow rise to the maximum, which was reachcd at 5 wccks. In contrast, the maximum level of ${ }^{3} \mathrm{H}$-proline incorporation into this protein was more than 10 -fold greater than normal and occurred at 3 weeks, as in most of the other proteins examined.

A peak in ${ }^{32} \mathrm{P}$ incorporation at 5 weeks was also seen for protein 48 , although the change developed more slowly and showed a greater degree of variability. In this case, the magnitude of the relative increase in ${ }^{32} \mathrm{P}$ incorporation approached that seen with ${ }^{3} \mathrm{H}$-proline.

Proteins showing no significant change in ${ }^{32} \mathrm{P}$ incorporation. A number of proteins appeared to maintain a relatively constant level of phosphorylation throughout regeneration, despite the usual pattern of increased ${ }^{3} \mathrm{H}$-proline incorporation (Fig. 4). These included proteins $10,35,42$, and 43 , as well as NF [probably the $130 \mathrm{kDa}$ neurofilament subunit (Perry et al., 1985)]. Alpha-tubulin has also been included in this category: although it showed an increased mean level of ${ }^{32} \mathrm{P}$ incorporation at 7 weeks (Fig. 4, last panel), there was great variability in this value, so that statistically it did not differ significantly from normal.

Proteins showing decreased phosphorylation. A striking finding was that some proteins showed a profound decrease in phosphorylation, despite increased ${ }^{3} \mathrm{H}$-proline incorporation with a time course resembling that of most of the other proteins (Fig. 5). One notable example was protein ON2 [an intermediate filament protein characteristic of goldfish optic axons (Quitschke 

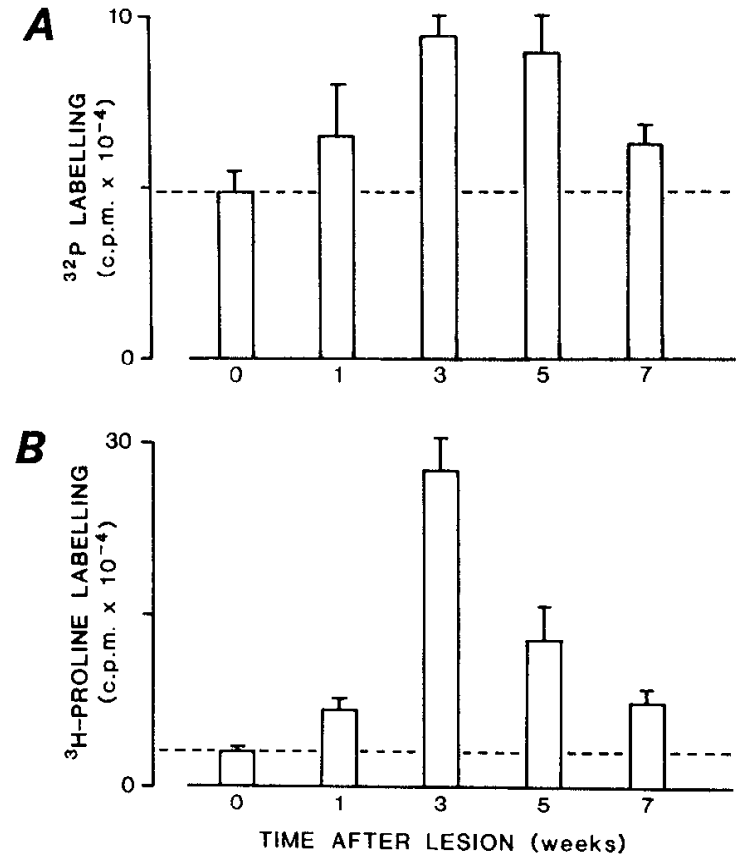

Figure 1. In vivo incorporation of $(A)^{32} \mathrm{P}$ and $(B){ }^{3} \mathrm{H}$-proline into total nerve protein during optic nerve regeneration. Goldfish were intraocularly injected with $50 \mu \mathrm{Ci}$ inorganic ${ }^{32} \mathrm{P}$ and $50 \mu \mathrm{Ci}^{3} \mathrm{H}$-proline. Seventeen hours later the optic nerves were excised and homogenized in a lysis buffer (see Materials and Methods). A $5 \mu \mathrm{l}$ aliquot was removed from each sample, precipitated with 5\% TCA, and solubilized with Soluene 100 before liquid scintillation counting. Each value is the mean of 4-6 measurements. Error bars indicate the SEM.

and Schechter, (1984)], in which incorporation was already significantly decreased by 1 week, reached its low of about $20 \%$ of normal by 3 weeks, and then showed some recovery, but was still at less than $50 \%$ of its normal value at 7 weeks (Fig. $5 \mathrm{~A}$ ). The changes in proteins 33 and 46 were very similar, except that 33 showed a faster recovery, with a return to normal levels by 5 weeks (Fig. 5A). Protein 37 showed the most profound decline, with its labeling virtually abolished at 3 weeks (Fig.

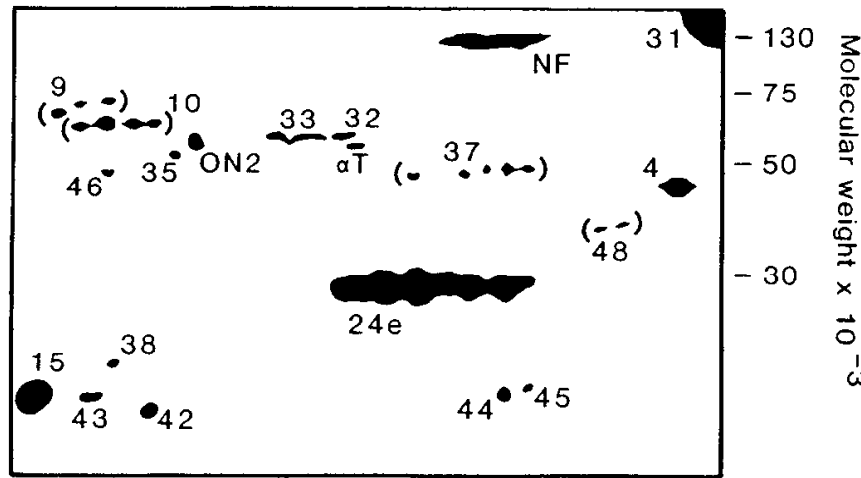

Figure 2. Representative map of phosphoproteins that become labeled in vivo in normal or regenerating goldfish optic nerves (Larrivee and Grafstein, 1987b). Optic nerve proteins labeled with radiophosphate as in Figure 1 were separated by 2-dimensional PAGE. Gels were then dried and exposed to Kodak X-OMAT film for $10 \mathrm{~d}$. The individual protein spots were identified by arbitrarily assigned numbers, consistent with previous studies (Perry et al., 1985, 1987; Larrivee and Grafstein, $1987 \mathrm{~b}$ ). Range of $\mathrm{p} I$ is from 7.0 (at left) to 4.4 .

$5 B)$. This protein also differed from the others in the group in that it did not yet show any significant decline at 1 week, its greatest decrease occurring between 1 and 3 weeks, and recovered very rapidly, returning to nearly normal values between 5 and 7 weeks. For another group of proteins, namely, 32, 44, and 45 , the decrease in ${ }^{32} \mathrm{P}$ labeling was evident only at 3 weeks (Fig. 5C). Protein 9 showed a unique pattern of changes, namely, a profound decrease in ${ }^{32} \mathrm{P}$ incorporation that was almost completely confined to the first week, whereas its ${ }^{3} \mathrm{H}$-proline incorporation showed an equally abrupt increase, reaching its peak at 1 week and gradually declining at 3 and 5 weeks.

Proteins showing changes in isoelectric point. A number of proteins displayed changes in isoelectric point in addition to changes in the amount of ${ }^{32} \mathrm{P}$ incorporation (Fig. 6). A particularly dramatic shift was observed for protein 9 , which in normal nerves appeared as a closely spaced row of 3 labeled spots. Following an abrupt decline in overall labeling intensity at 1 week, labeling of the protein began to recover at 3 weeks but
Figure 3. Plots of the time course of incorporation of ${ }^{32} \mathrm{P}$ (open circles, broken lines) and ${ }^{3} \mathrm{H}$-proline (closed circles, solid lines) into proteins (identified as in Fig. 2) which show increased ${ }^{32} \mathrm{P}$ incorporation during regeneration. $A-C$ illustrate different relationships between incorporation of ${ }^{32} \mathrm{P}$ and ${ }^{3} \mathrm{H}$-proline. Both ${ }^{32} \mathrm{P}$ and ${ }^{3} \mathrm{H}$-proline measurements were normalized to $100 \%$ of the maximum value obtained during the course of the experiment, as indicated by the ordinate at the left of each panel; the ordinate at the right of each panel indicates ${ }^{3} \mathrm{H}$-proline incorporation measured in cpm. Each value is the mean \pm SEM of 3-6 measurements. See text for further details.

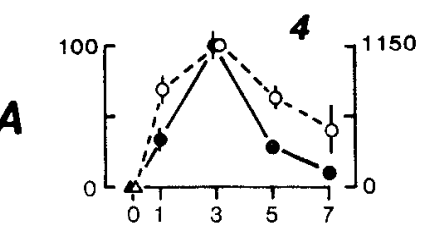

$0^{32} p$
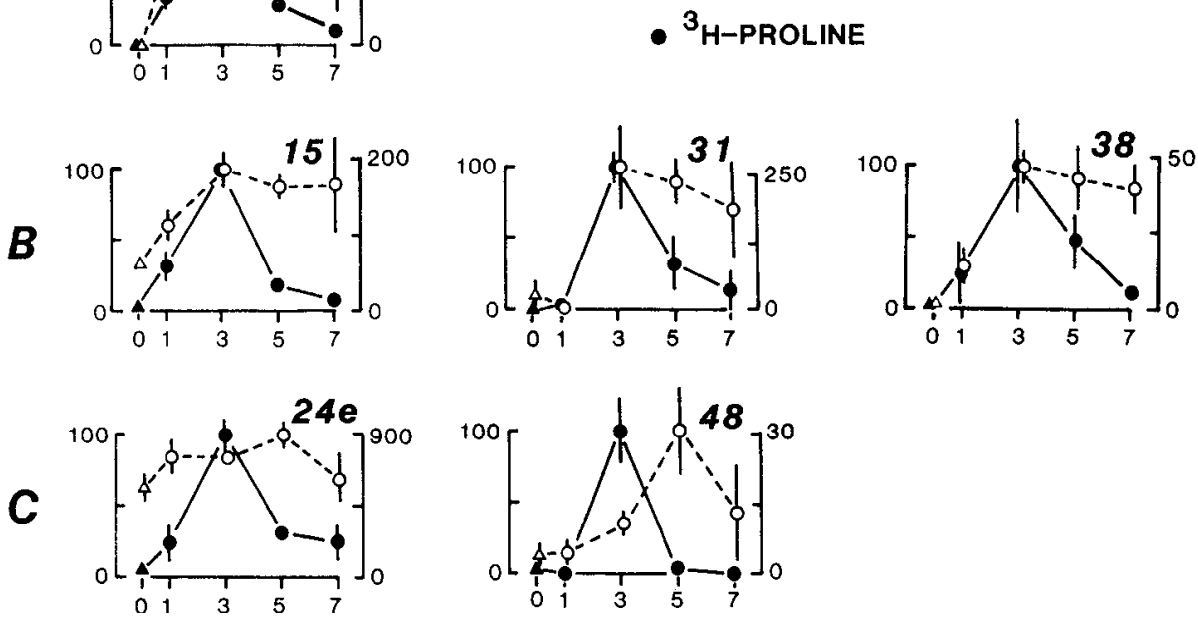

TIME AFTER LESION (weeks) 

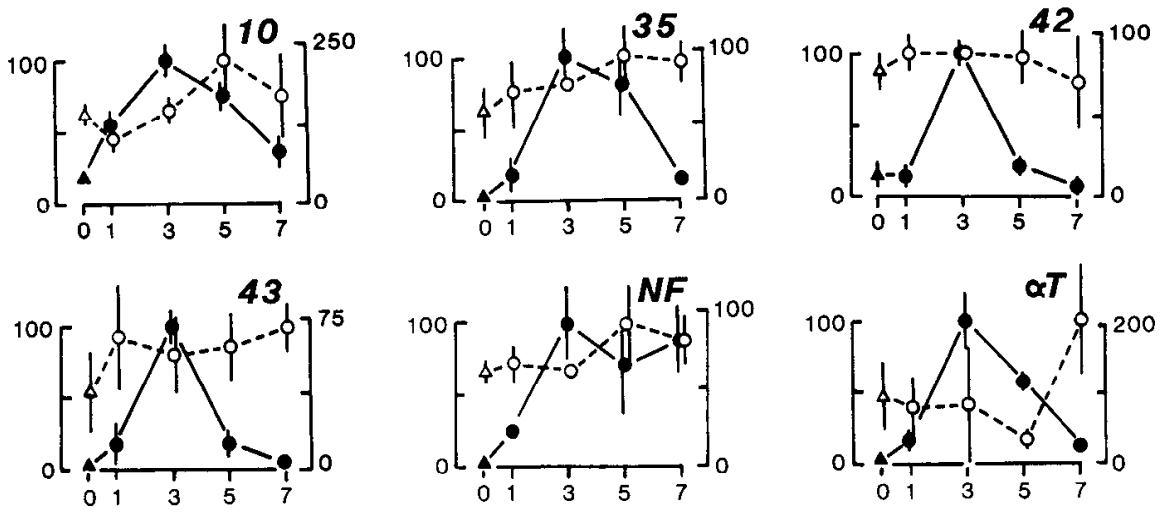

TIME AFTER LESION (weeks)

Figure 4. Plots of the time course of incorporation of ${ }^{32} \mathbf{P}$ (open circles, broken lines) and ${ }^{3} \mathrm{H}$-proline (closed circles, solid lines) into proteins showing no significant change in ${ }^{32} \mathrm{P}$ incorporation during regeneration. Details as in Figure 3. showed a shift to a more acidic $\mathrm{p} I$ with a somewhat broader displacement of the individual spots. The change in $\mathrm{p} I$, which amounted to about $0.3 \mathrm{pH}$ units, persisted through weeks 5 and 7. A prominent change during weeks 3-7 was also seen for protein $24 \mathrm{e}$, which became more basic in the regenerating nerve, causing the spot corresponding to this protein to have a blunter shape at its basic end (Fig. 6, arrow 3). In addition, a new spot appeared, which may represent a more basic isoform of this protein. A possible shift in $\mathrm{p} I$ of protein 33 at $1-3$ weeks was indicated by a relative increase in labeling of its more basic member (Fig. 6, arrow 5).

\section{Discussion}

Relationship of protein phosphorylation to nerve regeneration Most of the optic nerve proteins that we examined were present in relatively low abundance, even though they showed strong incorporation of ${ }^{32} \mathrm{P}$. This evidence of high specific activity of labeling is an indication that their phosphorylation may be critical to their function.

A major objective in the present study was to determine which proteins showed specific modulation of phosphorylation during various stages of regeneration. It is difficult, however, to define the duration of these "stages" precisely, even to differentiate between periods of axonal outgrowth and synaptogenesis. One problem is that a lesion of the optic pathway does not entail the same challenge for the whole retinal ganglion cell population: some axons have to grow farther than others before reaching the topographically appropriate tectal region in which synaptogenesis can begin. Even in an individual axon the transition from elongation to synaptogenesis may be a gradual one: rapid elongation ceases as the axon reaches the tectum, but the demand for elongation-associated elements does not necessarily

Table 1. Maximum changes in labeling of protein during regeneration of goldfish optic nerve

\begin{tabular}{|c|c|c|c|c|}
\hline & $\begin{array}{l}\text { Desig- } \\
\text { nation }^{a}\end{array}$ & $\begin{array}{l}{ }^{32} \mathrm{P}^{b} \\
\text { Regen./normal }\end{array}$ & $\begin{array}{l}{ }^{3} \mathrm{H} \text {-proline }{ }^{b} \\
\text { Regen./norm }\end{array}$ & \\
\hline \multirow[t]{6}{*}{ Proteins with increased phosphorylation } & 4 & $160 \pm 6$ & $230^{c} \pm 40$ & (4) \\
\hline & 15 & $3.0 \pm 0.4$ & $13.7 \pm 1.9$ & $(6)$ \\
\hline & $24 \mathrm{e}$ & $1.6 \pm 0.1$ & $20 \pm 3$ & (4) \\
\hline & 31 & $9.4 \pm 1.7$ & $53.4^{c} \pm 10.5$ & $5(4)$ \\
\hline & 38 & $22.5 \pm 2.7$ & $9.5^{c} \pm 3.7$ & (3) \\
\hline & 48 & $6.2 \pm 2.0$ & $6.2^{c} \pm 0.3$ & (4) \\
\hline \multirow[t]{8}{*}{ Proteins with decreased phosphorylation } & 9 & $0.07 \pm 0.04(3)$ & $5.0 \pm 0.6$ & (5) \\
\hline & 32 & $0.15 \pm 0.07(4)$ & $19^{c} \pm 4$ & (4) \\
\hline & 33 & $0.45 \pm 0.14(4)$ & $17 \pm 3$ & (4) \\
\hline & 37 & $0.03 \pm 0.01(4)$ & $10 \pm 2$ & (6) \\
\hline & 44 & $0.48 \pm 0.08(2)$ & $10^{c} \pm 1$ & (4) \\
\hline & 45 & $0.35 \pm 0.10(4)$ & $7.4 \pm 1.0$ & (4) \\
\hline & 46 & $0.45 \pm 0.18(3)$ & $5.0 \pm 0.8$ & $(5)$ \\
\hline & $\mathrm{ON} 2$ & $0.20 \pm 0.05(5)$ & $12.8 \pm 1.8$ & (4) \\
\hline \multirow{6}{*}{$\begin{array}{l}\text { Proteins with no significant change in } \\
\text { phosphorylation }\end{array}$} & 10 & $2.17 \pm 0.55(5)$ & $5.0+0.4$ & (4) \\
\hline & 35 & $1.58 \pm 0.34(4)$ & $19^{c} \pm 3$ & (3) \\
\hline & 42 & $1.35 \pm 0.43(4)$ & $7.0 \pm 0.4$ & (6) \\
\hline & 43 & $1.85 \pm 0.51(4)$ & $14^{c} \pm 3$ & (4) \\
\hline & $\alpha \mathrm{T}$ & $2.59 \pm 1.03(4)$ & $37 \pm 7$ & $(6)$ \\
\hline & $\mathrm{NF}$ & $1.52 \pm 0.40(5)$ & $18^{c} \pm 2$ & (4) \\
\hline
\end{tabular}

\footnotetext{
${ }^{a}$ Within each group, proteins are listed in order of numeric designation.

${ }^{b}$ Values are means \pm SEM; number of gels analyzed is given in parentheses.

c Normal values were within range of background variance, so calculated change is the minimum value that applies.
} 
Figure 5. Plots of the time course of incorporation of ${ }^{32} \mathrm{P}$ (open circles, broken lines) and ${ }^{3} \mathrm{H}$-proline (closed circles, solid lines) into proteins showing decreased ${ }^{32} \mathrm{P}$ incorporation during regeneration. $A-D$ illustrate different relationships between incorporation of ${ }^{32} \mathbf{P}$ and ${ }^{3} \mathrm{H}$-proline. Details as in Figure 3.
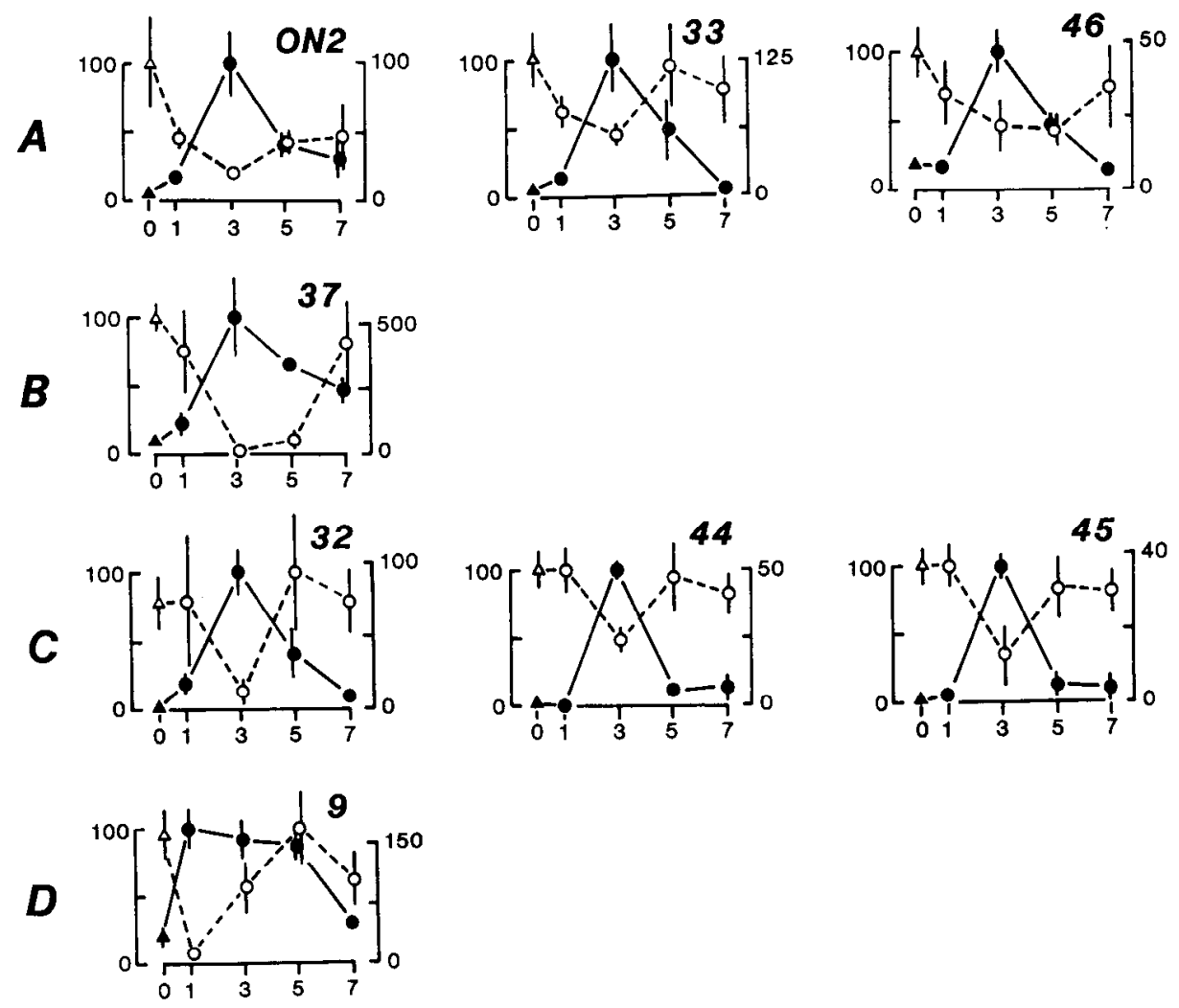

\section{TIME AFTER LESION (weeks)}

decline abruptly. Extensive axon branching occurs within the tectum, overlapping in time with synaptogenesis, and the axon branches continue to increase in volume for many weeks (Murray, 1976). Nevertheless, the period up to 3 weeks after axonal injury is primarily characterized by axonal elongation, and synaptogenesis is at a high level for at least another $2-4$ weeks, i.e., until the end of the period that we investigated in this study.

Only a few of the proteins that we examined showed phosphorylation changes specifically associated with one stage of regeneration. The changes in protein 9 , for example, consisting of an abrupt decline during the first week and a rapid recovery thereafter, appear to be correlated with the period of rapid axonal outgrowth. By contrast, protein 48 showed a change in phosphorylation that can be related to synaptogenesis - a slowly developing increase that reached a peak at 5 weeks.

Changes in some other proteins were less circumscribed but nevertheless appeared to be correlated more with one stage than the other. By the end of the first weck of regencration, phosphorylation of proteins $4, \mathrm{ON} 2$, and 33 had increased to more than $50 \%$ of the maximum change that they would undergo, and it already began to return toward normal between 3 and 5 weeks. Thus, these proteins respond primarily during the axon elongation phase. The differences among the proteins indicate that a variety of phosphorylating mechanisms is probably participating in this phase of regeneration.

The phosphorylation of several proteins, including 15, 31, 37, and 38 , was relatively little altered during the first week of regeneration but showed pronounced changes by 3-5 weeks. This suggested that their phosphorylation may be associated with synapse formation. Since proteins 15,31 , and 38 showed very little recovery even at 7 weeks, their phosphorylation may also be important for synapse maturation or refinement of the retinotectal projection (Constantinc-Paton and Law, 1982; Schmidt and Edwards, 1983).

Interestingly, proteins 32,44 , and 45 showed a decrease in phosphorylation confined to week 3 . It is possible that decreased phosphorylation of these proteins is associated with the initiation of synaptogenesis or with proliferation of axon sprouts within the tectum. It may be relevant that all 3 of these proteins are synthesized to a large extent in glial cells (Larrivee and Grafstein, 1987b).

\section{Significance of the changes in phosphorylation}

The absence of a correlation between phosphorylation and protein synthesis, which was the case for most of the proteins examined, implies that phosphorylation is a posttranslational event. In our system, much of the protein phosphorylation takes place within the axon (Larrivee and Grafstein, 1987c). The mechanisms regulating this phosphorylation are still unknown, but are likely to involve protein kinase activity. Another possibility is that phosphate residues are added at the time of synthesis but are removed to a variable degree by phosphatase activity (Ingebritsen and Cohen, 1983). Should this be the case, it would indicate a substantial elevation of phosphatase activity in the cell during regeneration, particularly in the case of proteins that show a net decrease in phosphorylation.

The closest parallel between ${ }^{32} \mathrm{P}$ and ${ }^{3} \mathrm{H}$-proline labeling was seen for protein 4 , which is closely related to, but not identical with, the growth-associated protein GAP-43 (Skene and Willard, 1981; Benowitz and Lewis, 1983). This is a fast-transported protein that shows greatly enhanced expression during axonal regeneration and development (Benowitz and Routtenberg, 

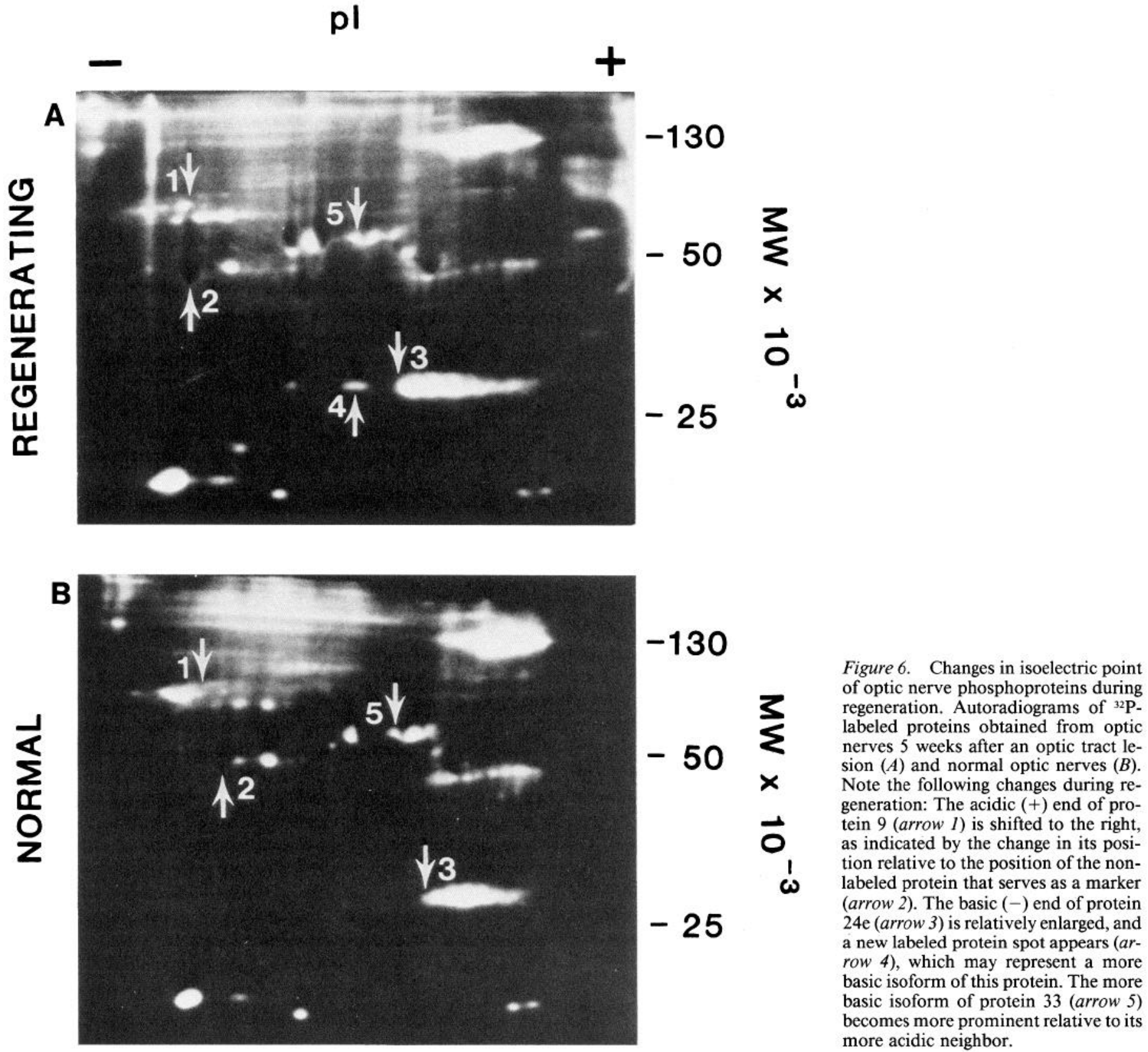

1987). It has been identified with neuromodulin, a neuron-specific, calmodulin-binding protein, which it greatly resembles in amino acid sequence (Basi et al., 1987; Cimler et al., 1987). The close correlation that we have shown between phosphorylation of the protein and its incorporation of ${ }^{3} \mathrm{H}$-proline suggests that the increased phosphorylation may be largely the consequence of an increase in the amount of protein available. Increased phosphorylation of GAP-43 has been found to be associated with long-term potentiation in the mammalian hippocampus (reviewed by Benowitz and Routtenberg, 1987). It is possible that the increased phosphorylation of protein 4 during goldfish optic nerve regeneration is similarly responsible for an enhanced degree of posttetanic potentiation in this system (Schmidt, 1987).

In addition to changes in the amount of ${ }^{32} \mathrm{P}$ incorporated into various proteins during regeneration, we have found evidence of changes in the degree of phosphorylation of some proteins, as indicated by changes in $\mathrm{p} I$. Thus, there may be changes not only in the number of molecules of a particular protein species that become phosphorylated, but in the number of sites that are labeled per molecule (and possibly changes in the nature of these sites). In general, a decrease in the number of phosphate groups in a protein molecule can be expected to result in a shift of the protein to the more basic side (Nixon et al., 1987). The functional significance of addition or removal of phosphate groups is likely to be different for various proteins, depending on their individual roles in the neuron, which remain to be determined.

The difficulties of interpreting the phosphorylation changes in the face of the multiplicity of mechanisms that might be involved have been well brought out by Nixon et al. (1987). It is clear that an understanding of the dynamics of phosphorylation would require measurements of values not only for ${ }^{32} \mathrm{P}$ incorporation, but for rates of synthesis, turnover, axonal trans- 
port, and intra-axonal deposition of the individual proteins, as well as their abundance.

Of the various proteins we examined, the most complete picture is available for protein ON2. This is an intermediate filament protein of neuronal origin (Quitschke and Schechter, 1984), which is conveyed by slow axonal transport (Perry et al., 1985). Our present observations of a large increase in incorporation of ${ }^{3} \mathrm{H}$-proline, reaching its maximum at about 3 weeks, correspond well with the time course of increased production of mRNA for this protein in the retina (Tesser et al., 1986). We found that its phosphorylation was significantly reduced by 1 week and showed a maximum reduction at 3 weeks, with some recovery thereafter. In the segment of optic axons between the lesion and the brain, the abundance of this protein is reduced with virtually the same time course (Perry et al., 1985). These changes presumably reflect the degeneration of the isolated axon segment followed by regeneration of axon sprouts that are initially deficient in neurofilaments (Lanners and Grafstein, 1980). Thus, the phosphorylation of this protein in the intact axon segment decreases in parallel with the decreased requirement for neurofilaments in the growing axon segment. In regenerating mammalian motor axons, there is likewise a reduction in the amount of phosphorylated neurofilament protein passing through the intact segment (Hoffman et al., 1985). This is the result of reduced synthesis and axonal transport of the protein (Hoffman et al., 1987). In the regenerating mammalian dorsal root ganglion cell, reduced delivery of phosphorylated neurofilaments to the axon is accompanied by their accumulation in the cell body (Goldstein et al., 1987), possibly indicating a defect in their transport into the axon. The decreased supply of phosphorylated neurofilament protein in the axon appears to be responsible for a reduction in axon diameter during regeneration (Hoffman et al., 1985). It may also enhance the rate of axonal elongation by reducing the likelihood of interaction between neurofilaments and neurotubules (Tetzlaff et al., 1987). It is interesting that in the goldfish optic nerve the reduction in the amount of phosphorylated neurofilament protein delivered to the regenerating axon is accomplished by a different mechanism, namcly, a decrcase in phosphorylation superimposed on an increase in synthesis.

ON2 is only one of the proteins in which the changes in ${ }^{3} \mathrm{H}-$ proline incorporation are not as well correlated with the progress of regeneration as the changes in phosphorylation. This indicates that, for regeneration of goldfish optic axons, regulation of posttranslational mechanisms for processing of proteins may be at least as important as regulation of gene expression.

\section{References}

Attardi, D. G., and R. W. Sperry (1963) Preferential selection of central pathways by regenerating optic fibers. Exp. Neurol. 7: 46-64.

Basi, B. S., R. D. Jacobson, I. Virag, J. Schilling, and J. H. P. Skene (1987) Primary structure and transcriptional regulation of GAP-43, a protein associated with nerve growth. Cell 49: 785-791.

Benowitz, L. I., and E. Lewis (1983) Increased transport of 44,000to 49,000 -Dalton acidic proleins during regeneration of the goldfish optic nerve, a 2-dimensional gel analysis. J. Neurosci. 3: 300-307.

Benowitz, L. I., and A. Routtenberg (1987) A membrane phosphoprotein associated with neural development, axonal regeneration, phospholipid metabolism, and synaptic plasticity. Trends Neurosci. 10: 527-532.

Burgess, S. K., N. Sahyoun, S. G. Blanchard, H. LeVine III, K.-J. Chang, and P. Cuatrecasas (1986) Phorbol ester receptors and protein kinase $C$ in primary neuronal cultures: Development and stimulation of endogenous phosphorylation. J. Cell Biol. 102: 312-319.

Cimler, B. M., D. H. Giebelhaus, B. T. Wakim, D. R. Storm, and R. T. Moon (1987) Characterization of murine cDNAs encoding P-57, a neural specific calmodulin binding protein. J. Biol. Chem. 262: 12158-12165.

Constantine-Paton, M., and M. I. Law (1982) The development of maps and stripes in the brain. Sci. Am. 247(12): 62-70.

Cremins J., J. Wagner, and S. Halegoua (1986) Nerve growth factor action is mediated by cyclic AMP and $\mathrm{Ca}^{2+}$ /phospholipid-dependent protein kinases. J. Cell Biol. 103: 887-893.

Girard, P. R., G. J. Mazzei, J. G. Wood, and J. F. Kuo (1985) Polyclonal antibodies to phospholipid/ $\mathrm{Ca}^{2+}$-dependent protein kinase and immunucylochemical localization of the enzyme in rat brain. Proc. Natl. Acad. Sci. USA 81: 3567-3571.

Goldstein, M. E., H. S. Cooper, J. Bruce, M. J. Carden, V. M.-Y. Lee, and W.W. Schlaepfer (1987) Phosphorylation of neurofilament proteins and chromatolysis following transection of rat sciatic nerve. J. Neurosci. 7: 1586-1594.

Grafstein, B. (1986) The retina as a regeneration organ. In The Retina: A Model for Cell Biology Studies, Vol. 2, R. Adler and D. Farber, eds., pp. 275-335, Academic, New York.

Grafstein, B., D. W. Burmeister, C. M. McGuinness, G. W. Perry, and J. R. Sparrow (1987) Role of fast axonal transport in regeneration of goldfish optic axons. Progr. Brain Res. 71: 113-120.

Hayes, W. P., and R. L. Meyer (1986) Retinotectal synapse numbers are regulated by an activity-independent and target-dependent mechanism in goldfish. Soc. Neurosci. Abstr. 12: 436.

Hoffman, P. N., G. W. Thompson, J. W. Griffin, and D. L. Price (1985) Changes in neurofilament transport coincide temporally with alterations in the caliber of axons in regenerating motor fibers. J. Cell Biol. 101: 1332-1340.

Hoffman, P. N., D. W. Cleveland, J. W. Griffin, P. W. Landes, N. J. Cowan, and D. L. Price (1987) Neurofilament gene expression: A major determinant of axonal caliber. Proc. Natl. Acad. Sci. USA 84: $3472-3476$.

Ingebritsen, T. S., and P. Cohen (1983) The protein phosphatases involved in cellular regulation: 1 . Classification and substrate specificities. Eur. J. Biochem. 132: 255-261.

Lanners, H. N., and B. Grafstein (1980) Early stages of axonal regeneration in goldfish optic tract: An electron microscope study. J. Neurocytol. 9: 733-751.

Larrivee, D. C., and B. Grafstein (1987a) In vivo phosphorylation of axonal proteins in goldfish optic nerve during regeneration. J. Neurochem. 48: 279-283.

Larrivee, D. C., and B. Grafstein (1987b) Phosphorylation of proteins in normal and regenerating goldfish optic nerve. J. Neurochem. 49: $1747-1757$

Larrivee, D. C., and B. Grafstein (1987c) Phosphorylation of proteins in regenerating goldfish optic nerve is independent of their synthesis and export into retinal ganglion cell axons. Soc. Neurosci. Abstr. 13: 1390.

Murphy, K. M. M., R. J. Gould, M. L. Oster-Granite, J. D. Gearhart, and S. H. Snyder (1983) Phorbol ester receptors: Autoradiographic identification in the developing rat. Science 222: 1036-1038.

Murray, M. (1976) Regeneration of retinal axons into the goldfish optic tectum. J. Comp. Neurol. 168: 175-196.

Murray, M., and M. A. Edwards (1982) A quantitative study of the reinnervation of the goldfish optic tectum following optic nerve crush. J. Comp. Neurol. 109: 363-373.

Nestler, E. J., S. I. Walaas, and P. Greengard (1984) Neuronal phosphoproteins: Physiological and clinical implications. Science 255: 1357-1364.

Nixon, R. A., S. E. Lewis, and C. A. Marotta (1987) Posttranslational modification of neurofilament proteins by phosphate during axoplasmic transport in retinal ganglion cell neurons. J. Neurosci. 7: 1145-1158.

O'Farrell, P. (1975) High resolution two-dimensional electrophoresis of proteins. J. Biol. Chem. 250: 4007-4204.

Perry G. W., D. W. Burmeister, and B. Grafstcin (1985) Changes in protein content of goldfish optic nerve during degeneration and regeneration following nerve crush. J. Neurochem. 44: 1142-1151.

Perry G. W., D. W. Burmeister, and B. Grafstein (1987) Fast axonally transported proteins in regenerating goldfish optic axons. J. Neurosci. 7: 792-806.

Quitschke, W., and N. Schechter (1984) 58,000 Dalton intermediate filament proteins of neuronal and nonneuronal origin in the goldfish visual pathway. J. Neurochem. 42: 569-576.

Schmidt, J. T. (1987) Increased potentiation of postsynaptic responses correlated with sensitive period during optic nerve regeneration in goldfish. Soc. Neurosci. Abstr. 13: 241. 
Schmidt, J. T., and D. L. Edwards (1983) Activity sharpens the map during the regeneration of the retinotectal projection in goldfish. Brain Res. 269: 29-39.

Skene, J. H. P., and M. Willard (1981) Changes in axonally transported proteins during regeneration in toad retinal ganglion cells. J. Cell Biol. 89: 86-95.

Tesser, P., P. Jones, and N. Schechter (1986) Elevated levels of retinal neurofilament mRNA accompany optic nerve regeneration. J. Neurochem. 47: 1235-1243.

Tetzlaff, W., M. A. Bisby, C. A. Krekoski, and I. M. Parhad (1987) A conditioning lesion does not further stimulate tubulin and actin synthesis but further decreases neurofilament synthesis in the facial nucleus of the rat. Soc. Neurosci. Abstr. 13: 291.

Turner, R. S., RI. L. Raynor, P. R. Mazzei, P. R. Girard, and J. F. Kuo (1984) Developmental studies of phospholipid-sensitive $\mathrm{Ca}^{2+}$-dependent protein kinase and its substrates and of phosphoprotein phosphatases in rat brain. Proc. Natl. Acad. Sci. USA. 81: 3143-3147.

Whitnall, M. H., and B. Grafstein (1982) Perikaryal routing of newly synthesized proteins in regenerating neurons: Quantitative electron microscopic autoradiography. Brain. Rcs. 239: 41-56. 